\title{
Assessment of value added and development opportunity of agroindustry activity based on marine resources in Sub District of Panarukan, District of Situbondo
}

\author{
Syamsul Hadi', M. Iwan Wahyudi, M. Hazmi, and Henik Prayuginingsih \\ Agriculture Faculty of University of Muhammadiyah Jember, Jember 68121 East Java, Indonesia
}

\begin{abstract}
Sub-District Panarukan, Distric of Situbondo has many food processing and non-food processing centers based on marine resources, all of which reaches 197 business units which include: Craft, Fish Cracker, Fish Chips, Shrimp paste and rengginang fish. The socio-economic phenomena of coastal communities should provide added value, absorb a lot of unemployment, but the people are still not prosperous in economically. The purposes of this study are to: Analyze the value added of resource-based on agroindustry, and to know the opportunity of marine resource development based agroindustry. The type of research used is descriptive with survey technique. Furthermore, the excavated data consists of qualitative and quantitative data which collected by using depth interview technique and the determination of respondents is done by simple random sampling technique. In order to answer the first, and second, the Hayami value-added analysis, and cost efficiency (R/C-Ratio) are used. The result of the research revealed that the ratio of added value of agribusiness activity of marine basis is $37,5 \%$ (value added ratio $15 \%-40 \%$ ), then the added value is classified. While the business opportunity of agribusiness activity in the research area is very big which indicated the value of $\mathrm{R} / \mathrm{C}$ reach 1.95 . If marine resourcebased agroindustry activities in the research area are intervened with a touch of modern science-based management, then the value-added ratio potentially reaches more than $40 \%$ ( $>40 \%$ high added value categories).
\end{abstract}

\section{Introduction}

The number of industrial companies in District of Situbondo in 2014 can be explained as follows: small industries and household handicrafts 12.726 units (up 3.00\% from 2013) with a workforce of 44,725 people (up $5.00 \%$ from 2013). Of the 12.726 units of small scale industries and household handicrafts, 4,436 businesses or $34.86 \%$ employed 19.989 workers, Textile / Sewing 681 businesses or $5.35 \%$, tile 435 businesses or 3, 42\% and bamboo woven 253 businesses or $1.99 \%$ and other industries under 1\%. Furthermore, in District of

\footnotetext{
*Correspondent Author : syamsul.hadi@unmuhjember.ac.id
} 
Situbondo, the number of Scallop Craft is 367 business units with 1,307 workers and investment value of IDR 43.7830.000, -, the production value is IDR 4,405,824,000, - and the raw material value reaches IDR 1.938.499.000 (BPS Situbondo, 2015). Meanwhile, the number of shrimp raw materials processing industry reached 18 business units absorbing labor 139 people with investment value IDR 75.483.000, -, production value IDR 663.705.000, - and raw material value IDR 349.209.000, -. Based on the development of Industrial Enterprises by as much as of Business Unit, Manpower, Investment, Value of Production and Raw Material of agroindustry based on marine resources are respectively reached Agro 4.452 business unit, 20.057 people, IDR 7.999.202.000, - IDR 51.108.545.000, - and IDR 22.771.979.000, -.

Panarukan is one of the sub-district of Situbondo, located adjacent to the city of Situbondo with the height of the village from sea level is between $3 \mathrm{~m}$ to $15 \mathrm{~m}$. The width of Sub-district of Panarukan is $54,55 \mathrm{Km} 2$ or $5.455 \mathrm{H}$ consisting of 8 villages having many food processing and non-food processing centers based on marine resources. Because four of the eight villages in Sub-district of Panarukan, Kilensari Village, Peleyan Village, Duwet Village and Gelung Village have coastal areas. The number of business units, absorbed labor, and the value of production of food and non-food processing industries based on agricultural commodities and marine resources in Subdistrict of Panarukan, District of Situbondo are presented in table 1 below.

Tabel 1 Distribution of Food and Non-Food Processing Industry Based on Agricultural Commodities and Marine Resources in Subdistrict of Panarukan, District of Situbondo Year 2014

\begin{tabular}{|c|c|c|c|c|}
\hline No & $\begin{array}{c}\text { Type of } \\
\text { Agroindustry }\end{array}$ & $\begin{array}{c}\text { Quantity of } \\
\text { Business unit }\end{array}$ & $\begin{array}{c}\text { Quantity of } \\
\text { Labor } \\
\text { (Person) }\end{array}$ & Production Value (IDR) \\
\hline 1 & Craft shells & 96 & 470 & 1.258 .573 .000 \\
\hline 2 & Fish crackers & 46 & 310 & 182.732 .000 \\
\hline 3 & Coconut shell bag & 32 & 70 & 110.666 .000 \\
\hline 4 & Fish chips & 6 & 50 & 124.023 .000 \\
\hline 5 & Cracknel & 17 & 95 & 338.164 .000 \\
\hline & Total & 197 & 995 & 2.014.158.000 \\
\hline
\end{tabular}

Source: BPS District of Situbondo, Year 2015

Agroindustry activities in Soekartawi's opinion (2008) can increase the income of agribusiness actors, able to absorb labor, increase foreign exchange earnings and most importantly able to encourage the emergence of other industries. The indication of the opportunity for the development of agroindustry in the coastal area is supported by the marketing system built up so far, the products are sold directly to the nearest traditional market and the final consumer and the direct collectors come to the craftsman's house. The marketing opportunities of fishery-based agro-industry products in coastal areas are also increasingly wide open. This is because Pathek Beach in Village of Duwet and Gelung and fish harbor in Village of Kilensari is reconstructed into a national-type harbor and Peleyan Village has Fish auction to support the marketing of catch fish for Fish auction in Kilensari which was first established.

Marketing Efficiency and Prospect of Agroindustry Development of Fish Cracker in Village of Gelung, concluded that marketing channel of fish cracker agroindustry consist of three channel that is zero level channel, first level channel and second level channel but the most efficient is one-tier marketing channel of $0.2 \%$. The prospect of fish cracker agroindustry is based on the results of SWOT Analysis in the position of White Area with emphasis on S-O strategy (Stength-Opportunities). However, the added value problem and the prospect of marine resource based agroindustry activities are not yet known. So there is 
no information on the matter that can be conveyed to the policy makers as a material consideration in the development effort in the field of food processing industry and handicrafts. Therefore, it is deemed necessary to study more deeply about the study of added value and prospect of marine resource based agroindustry considering Sub District of Panarukan has been known for centuries as the biggest fish producing area in District of Situbondo and as a supplier area for other districts in East Java. Processed food products such as fish 'rengginang', fish crackers, fish chips, and souvenir products such as craft shells is a potential development of agroindustry that can provide added value on export quality marine resources.

The hope is to expand employment opportunities and increase the income of coastal communities living on the line and / or below the poverty line of $\pm 21.15 \%$. Although the potential of marine resources in the region contains tremendous expectations in the growth and movement of the economy, there are still many obstacles encountered, among others (Soejono, 2008): (1) marketing conditions that do not encourage the development of consumption, distribution of fishery products; (2) quality standards or quality of fish catch and sanitation; (3) relatively low equipment condition and application of technology in sea fishing activities; (4) the ratio of the amount of capital and the level of capital cost required is still very low; (5) Environmental issues are a lot of complaints and are used as an excuse to reject or restrain the marketing of fish; and (6) lack of development of the processing industry of fishery products in the coastal areas. Starting from the various problems faced by the fishermen community, one of the alternative options for problem solving that can be done is the development of agroindustry of the catches processing which the organization and its management are rationally designed to get maximum commercial value added by producing the product according to market demand.

The potential of agro-industry development through the development of marine resourcebased household industry Sub-district of Panarukan, District of Situbondo is faced with various problems that start from the main problem that is the level of knowledge and skill is still limited, the ownership of business capital is relatively limited, scattered production activities in non-group, business capital loans, technology and markets are relatively difficult. Such conditions lead to productivity due to work motivation to be weak, which in turn implies the movement of downstream become slow. Craftsmen engaging in agro-industry activities are driven only by routine orientation due to traditional factors without considering performance improvement. Based on the above phenomenon, then the aims of the study are: 1) to analyze the value added of agroindustry based marine resources in Subdistrict of Panarukan, District of Situbondo; and 2) to know the opportunity of marine resource development based agroindustry in Subdistrict of Panarukan, District of Situbondo.

\section{Research Methods}

\subsection{Research model}

The study employed survey method to see how far the condition of agroindustry activity and its development opportunities in research area objectively and factually, potential and existing problem [1]

\subsection{Location, Time and Research Population}

The location of this research is the Subdistrict of Panarukan, district of Situbondo precisely the location of the village which has the center of marine resource based agroindustry which includes Village of Gelung, Kilensari, Paowan, Duwet, Peleyan and 
Wringinanom. The termination of research location is determined by purposive sampling on the consideration that in that location is a center of food processing and non-food processing industry based on marine resources. This research has been done in July till September 2017. The study population is craftsmen agroindustry based marine and non-food resources (nonfishermen) are determined intentionally through techniques of non-probability sampling. The research sample is determined proportionally stratifield random sampling based on the type of agroindustry they do.

\subsection{Resources and Data Collection Techniques}

Based on the source that the data collected in this study includes primary data and secondary data. Primary data were obtained from the craftsmen collected by combining several complementary data collection techniques, namely: FGD and Indepth Interview. This data collection technique is guided by a list of questions prepared beforehand for the purpose of collecting data information can be directed and systematic and can answer the issues under review. The secondary data were collected from related institutions with this research.

\subsection{Data analysis}

\section{Answer the First Goal}

The amount of added value that can be known by Hayami method that can also be used to find information about the amount of income for direct labor and profits regardless of fixed costs. This research uses value-added calculation method for processing with [2]. There are three indicators of value added ratio [3] that are:

1) If the value added ratio $<15 \%$, then the added value is low;

2) If the value added ratio is $15 \%-40 \%$, then the added value is medium; and

3 ) If the value added ratio $>40 \%$, then the value added is high.

\section{Answer the Second Objective}

The R / C Ratio analysis shows the amount of business opportunity where R / C stands for Revenue Cost Ratio, which is the ratio between acceptance and cost as the following formulation [4] R / C =Total Revenue (TR) / Total Cost (TC), Where:

$\mathrm{R}=\mathrm{TR}=$ Acceptance $=\mathrm{P} . \mathrm{Q}$

$\mathrm{TC}=\mathrm{TFC}+\mathrm{TVC}$

$\mathrm{FC}=$ Fixed Cost

$\mathrm{VC}=$ Variable Cost

The criteria used in the analysis of $\mathrm{R} / \mathrm{C}$ ratio as follows:

- If the $\mathrm{R} / \mathrm{C}$ ratio of $>1$ business is said to be viable and profitable,

- If the $\mathrm{R} / \mathrm{C}$ ratio of $<1$ business is said to be unfit to continue,

- If the value of $\mathrm{R} / \mathrm{C}$ ratio $=1$ business is said to be break even (no profit and no loss).

\section{Results And Discussion}

\subsection{Value Added Study Agroindustry Based on Marine Resources}

Based on the potential in the research area, some commodities and agroindustry products that can be developed include sea fish and non fish. In the opinion of that value added analysis 
is a value addition to a product after further processing. Value-added analysis will provide information on factors of the production process that produce or increase added value and vice versa. The following will discuss the results of value-added analysis of agroindustry based on marine resources as presented in Table 2 below.

\subsection{Output, Input, and Price}

Respondents of marine resource based agroindustry are referred to in this research is divided into five groups, the respondents group agroindustry craft souvenirs shells, rengginang shrimp paste, shrimp paste, dried fish and fish crackers. Actually there are still other craftsmen who are not includes in this research respondents, namely seaweed craftsmen and sea fish abon because of time, cost and energy. Most of the respondents $(85.25 \%)$ obtained their raw materials in agro-industry activities by buying from fishermen or other parties, and the rest (14,75\% of respondents) came from sea fish catch themselves.

The result of value added analysis using Hayami and Ruttan model, 1989 as presented in Table 1 reveals that from marine resource based agroindustry activities through five types of products produced value added as much as IDR $14.222,25$ per kg per production process . It is known that the production process in the past business activity takes between $1-21$ days, in which the making of shell souvenir takes 7 days, rengginang need $4-5$ days, shrimp paste takes 21 days, dried fish and fish crackers each takes 5 days and \pm 9 days. The added value ratio of marine resource-based product processing process reaches $34.95 \%$ and is classified as moderate $(15 \%-40 \%)$ according to [3] and higher than jackfruit chips agroindustry from in Lumajang and in Cikeas, Bogor Regency with value added ratio of 21,79\% and 26,52\%, respectively.

When compared with the value added value of marine fish based agroindustry activities in Dusun Payangan Sumberejo Village Ambulu District Jember Regency by [5] which is high $(40 \%)$, then the value added ratio in this research area is still lower. This is because the agroindustry activity in this study area average raw material price (IDR $15.528,69 / \mathrm{kg}$ ) is higher than the result of research in Payangan Hamlet (IDR 10.952,38 / kg), while the price of handicraft product in this research area (IDR $37.606,56 / \mathrm{kg}$ ) is lower than in the area of Dusun Payangan $(61.023,81 \mathrm{~kg})$. It can be explained that at the time of this research, the craftsmen respondents in Subdistrict of Panarukan enter the famine season, so they have to buy raw materials from outside the region with high price, except craftsmen rengginang where raw material glutinous rice which is relatively stable even though they have to buy relief ingredients shrimp paste and fish is also relatively high.

Tabel 2 Results of Value Added Analysis of Marine Resource Based Agroindustry Subdistrict of Panarukan, District of Situbondo Year 2017

\begin{tabular}{|l|l|r|c|}
\hline \multicolumn{2}{|c|}{ Output, Input, Price } & Formula Value & Formula \\
\hline 1 & Amount of production $(\mathrm{kg} / \mathrm{pp})$ & 49.81 & $\mathrm{~A}$ \\
\hline 2 & Raw material $(\mathrm{kg} / \mathrm{pp})$ & 46.03 & $\mathrm{~B}$ \\
\hline 3 & Labor (MWD) & 4.77 & $\mathrm{C}$ \\
\hline 4 & Conversion factor (1 / 2) & 1.08 & $\mathrm{~A} / \mathrm{B}=\mathrm{M}$ \\
\hline 5 & Koefisien of Labor (3/2) & 0.10 & $\mathrm{C} / \mathrm{B}=\mathrm{N}$ \\
\hline 6 & Product Price (IDR / Kg) & $37,606.56$ & $\mathrm{D}$ \\
\hline 7 & Average wages (IDR / MWD) & $30,336.07$ & $\mathrm{E}$ \\
\hline \multicolumn{2}{|l|}{ Income and Profits * } & & \\
\hline 8 & Raw material Price (IDR / kg) & $15,528.69$ & $\mathrm{~F}$ \\
\hline 9 & Donations of other inputs (IDR / kg) & $10,942.62$ & $\mathrm{G}$ \\
\hline 10 & Revenue (4x6) (IDR / kg) & $40,693.56$ & $\mathrm{M} \mathrm{x} \mathrm{D}=\mathrm{K}$ \\
\hline 11 & a. Added Value (10-9-8) (IDR / kg) & $14,222.25$ & $\mathrm{~K}-\mathrm{F}-\mathrm{G}=\mathrm{L}$ \\
\hline
\end{tabular}




\begin{tabular}{|c|c|c|c|}
\hline \multicolumn{2}{|r|}{ Output, Input, Price } & Formula Value & Formula \\
\hline & b. Ratio Added Value (11.a / 10) (\%) & 34.95 & $(\mathrm{~L} / \mathrm{K}) \%=\mathrm{H} \%$ \\
\hline \multirow[t]{2}{*}{12} & a. Employee benefits (5x7) (IDR / kg) & $3,143.80$ & $\mathrm{~N} \times \mathrm{E}=\mathrm{P}$ \\
\hline & b. Parts of labor (12.a. / 11.a.) (\%) & 22.10 & $(\mathrm{P} / \mathrm{L}) \%=\mathrm{Q} \%$ \\
\hline \multirow[t]{2}{*}{13} & a. Profits $(11 a-12 . a)(I D R / k g)$ & $11,078.45$ & $\mathrm{~L}-\mathrm{P}=\mathrm{R}$ \\
\hline & b. Profit rate (13.a / 11a) (\%) & 77.90 & $(\mathrm{R} / \mathrm{L}) \%=\mathrm{O} \%$ \\
\hline \multicolumn{4}{|c|}{ Balas Jasa Untuk Faktor Produksi** } \\
\hline 14 & Margin (IDR / kg) & $25,164.87$ & $\mathrm{~K}-\mathrm{F}=\mathrm{S}$ \\
\hline 15 & Direct labor income $(12 \mathrm{a} / 14) \times 100 \%$ & 12.49 & $(\mathrm{P} / \mathrm{S}) \times 100 \%=\mathrm{T}$ \\
\hline 16 & Donations of other inputs $(9 / 14) \times 100 \%$ & 43.48 & $(\mathrm{G} / \mathrm{S}) \times 100 \%=\mathrm{U}$ \\
\hline 17 & Corporate profits (13a / 14) x 100\% & 44.02 & $(\mathrm{R} / \mathrm{S}) \times 100 \%=\mathrm{V}$ \\
\hline
\end{tabular}

Table 2 above illustrates that the average labor allocation of 4,77 MWD on the use of raw material input is $46,13 \mathrm{~kg}$ per production process with an average wage of labor of IDR 30.336,07 / Men's Working Days (MWD) per production process. It can be explained that one MWD is 7,5 working hours or one adult work day in a day with 8 hours applicable in the research area. The amount of labor coefficient value shows the amount of labor donation needed to process one kilogram of raw materials of sea fish and shellfish. Meanwhile, the conversion factor value is the ratio of output to input, where in this study the average conversion value of 1,08 and the average value of labor coefficient of 0,10 . On the basis of the average conversion value and labor coefficient can be interpreted that to process 100 kilograms of raw materials to be 108 kilograms of processed products required direct labor as much as 100 MWD. From the value of the coefficient of labor can be seen whether the entrepreneur has been efficient production or not. The smaller the value of the coefficient of labor the more efficient the producer produces. In this context the use of labor as much as 4.77 MWD to process raw materials of sea fish as much as $46.13 \mathrm{~kg}$ to produce processed production of $49,67 \mathrm{~kg}$ is not efficient in one production process. Similarly, the activities of agroindustry in this research area are relatively the same level of efficiency with the result of [6] research in Payangan Hamlet Sumberejo Subdistrict of Ambulu Sub-district of Jember Regency.

The share of labor received per $\mathrm{kg}$ of processed raw material only gained a share of $22,10 \%$ per $\mathrm{kg}$, where the percentage is higher than the result of research in Lumajang Regency about value added of nangka chips agroindustry which percentage reaches $17.40 \%$ . This is due to the power conversion factor $(0,10)$ in this study is lower than the results of his research which reached the value of 0,18 . These conditions further indicate that the use or allocation of labor in agroindustry activities in this research area is relatively more efficient, so it will have implications on the level of profit that can reach $77,90 \%$. If the profit level is compared with the result of Hadi and Farhiyah research (2016) in Dusun Payangan Desa Sumberejo Subdistrict of Ambulu of Jember Regency which reaches 91,30\%, the profit level in this research area is still lower.

\section{Revenue and Profit}

The result of calculation of value added analysis obtained from marine resource based agroindustry in research area shows that the average value added is IDR 14.222,25 per kilogram of raw material. Value added calculation aims to know the value added value in one kilogram of marine fish after processed into pindang fish, smoke and shrimp paste. The amount of added value depends on the cost incurred including the average cost of raw material purchases amounting to IDR 15,528.69 per kilogram ranging from IDR 12.000, - s.d Rp 55.000, - per kilogram and other input contribution of IDR 10.942.62 per unit. Other input contributions consist of all variable costs except raw material costs and labor costs. Other 
inputs in it include the cost of purchasing auxiliary materials (herbs, salts, and additives), fuels, glue (Autosol), dyes, rubber tires, strings, straps, polishes, and packaging.

Table 2 above also reveals that the average profit earned from agro-industry activities is IDR $11.078,45$ per kilogram for return on capital and management with an average profit rate of $77.90 \%$ of the added value of the product which means every kilogram of processed products. The average profitability and profitability in the research area is much lower than that of [5] in the above Payangan Hamlet, each of which reached IDR 39.870,74 in return for capital and management and $91,30 \% \mathrm{~kg}$ of raw materials. This condition is caused by the price of raw materials in this research area is much higher, and the price of handicraft product is much lower although the labor usage is relatively the same. Similarly, when compared with research results in Lumajang on value added analysis of jackfruit agroindustry, the average profit rate is $82,60 \%$ or higher than the average profit rate in this study area. This condition is caused by the conversion factor is 1,8 and the labor coefficient of 0,13 , so it will affect the amount of added value.

\section{Reply Services for Production Factors}

Production factor services consist of remuneration for labor production factors, other inputs, and rate of return. Margin is the difference in price or value of the product with the input value of the raw materials used. Margin will be distributed in return for labor, other input contributions, and profits of the company or craftsman. The average margin of processed production is IDR $25.164,87$ per kilogram of raw material consisting of $12,49 \%$ direct labor income, $43,48 \%$ contribution of other inputs, and $44.02 \%$ of craftsman profits. The company's profit margin is the largest and largest margin compared to the labor income margin. It shows that marine resource based agroindustry effort in research area is labor intensive business. In other words, the agro-industry activities can absorb a lot of manpower and become the main alternative in increasing population income and reduction of unemployment in coastal area.

\subsection{Development Opportunity of Agroindustry Based on Marine Resources}

Revenue Cost Ratio Analysis ( $\mathrm{R}$ / C Ratio) is an analysis tool to see the relative profit of a business in one year to the cost used in the activity or better known as cost efficiency analysis to know the chances of a productive economic enterprise. The result of financial analysis of marine resources based agrooindustry business is shown in Table 3 .

Tabel 3. Result of Finansial Analysis of Business Opportunity of Agroindustry Activity Based on Marine Resources at Subdistrict of Panarukan of District of Situbondo Year 2017 (in one process producer)

\begin{tabular}{|l|l|c|r|r|r|}
\hline No & Descriptions & Unit & Quantity & Price/Unit & Value/Account (IDR) \\
\hline A & Operational Cost: & & & & $\mathbf{9 5 8 , 9 3 2}$ \\
\hline & 1. Depreciation Tools & $\mathrm{Ls}$ & 1 & 15,000 & 15,000 \\
\hline & 2. Raw Materials & $\mathrm{Kg}$ & 46.03 & 15,529 & 714,829 \\
\hline & 3. Helper Material & $\mathrm{Ls}$ & 2 & 10,943 & 21,885 \\
\hline & 4. Fuel & $\mathrm{Ls}$ & 2.5 & 17,000 & 42,500 \\
\hline & 5. Labors & $\mathrm{MWD}$ & 4.77 & 30,336 & 144,718 \\
\hline & 6. Letters (Packing) & $\mathrm{Unit}$ & 2 & 10,000 & 20,000 \\
\hline B & Amount of production & $\mathrm{Kg}$ & $\mathbf{4 9 . 8 1}$ & & \\
\hline C & Price of Agroindustry Product & $\mathrm{Kg}$ & & $\mathbf{3 7 . 6 0 7}$ & $\mathbf{1 . 8 7 3 , 2 3 8}$ \\
\hline D & Total Revenue (TR) & & & & \\
\hline
\end{tabular}




\begin{tabular}{|l|l|l|l|l|r|}
\hline No & Descriptions & Unit & Quantity & Price/Unit & Value/Account (IDR) \\
\hline E & Opportunity (R/C) & & & & 1.95 \\
\hline
\end{tabular}

Table 3 above shows that the marine resource based agroindustry business opportunity in the research area is quite large, as evidenced by the $\mathrm{R} / \mathrm{C}$ ratio of 1,95 in one production process. This means that each fisherman's expense per IDR 1, - will generate income of IDR 1,95 , -. When compared with [6] in Puger where the value of $\mathrm{R} / \mathrm{C}$ ratio on agroindustry activity of shrimp paste, fish cracker, dried fish, fogging (fumigation) fish and fish meal are $1.82,1.32,1.31$, and 1.17, respectively. Even in 2012 Pudjanarso's research on value-added study and the break-even point on fish stocks in the same area, the $\mathrm{R} / \mathrm{C}$ ratio is only 1.21 . Along with the increasingly skilled sea fish craftsmen in the research area, the level of processing cost efficiency is higher in addition to the price of processed products is also higher. Therefore, the value of agroindustry development opportunities in the research area is increasingly high.

Unlike the results of research [5] in Dusun Payangan Sumberejo Ambulu Jember regency, where it can be disclosed that the group of respondents who act as fishermen as well as crafters have average $\mathrm{R} / \mathrm{C}$ ratio on craft activities reached 3.84, while for the group of respondents only acting as a craftsman only average $\mathrm{R} / \mathrm{C}$ ratio reaches 5,31 . This condition caused in the first group of respondents intensification of agroindustrial business is not running maximally because the management concentration is split on fishing activity. While in the second group of respondents, more concentration on the management of one activity only with no fear of lack of raw materials because it has established strong cooperation with some fishermen.

The condition of socio-cultural factors of coastal communities in each region has different traditions and economic endeavors. This is because the environment is very strong influence on the characteristics of the way of management of a business one's economy besides influenced by geostrategic factors, geopolitics, and local government regulations. Following in detail will be discussed about financial analysis to reveal how big business opportunities based agroindustry marine resources by type of craft business in the study area.

\section{Conclusion}

1. The result of value added analysis using Hayami model in this research reveals agroindustry activity based on marine resources through five types of products produced gives added value as much as IDR 14.222,25 per kg per production process. The average price of raw materials is IDR $15.528,69 / \mathrm{kg}$, the price of handicraft products is IDR $37.606,56 / \mathrm{kg}$ with the average labor allocation of 4,77 MWD on the use of raw material input of 46,13 $\mathrm{kg}$ per production process with average wage the average workforce of IDR 30.336,07/MWD per production process and other input contributions amounted to IDR $10.942,62$ per unit.

2. The average fishing business opportunity in the research area is quite large, it is proved by the $\mathrm{R} / \mathrm{C}$ ratio of 1,95 in one production process. Detailed business opportunity of Agroindustry Souvenir of Leather Shell reach 3.83, Rengginang agroindustry activity financially have big enough business opportunity with R/C Ratio 2.02, Shrimp paste reach 1.56, Dry fish reach 1.66, and Fish Cracker of 2,76. The profit level obtained by the five types of agroindustry is enough with an average of IDR 914,306, - each production process with a range from IDR 106.195, - to IDR 1.737.770, -.

\section{Acknowledgements}


Thanks to the authors say to the Institute of Research and Community Service UM Jember who has supported research funds through Internal Research Scheme Fiscal Year 2017. In addition, we would also like to thank the Director of Intellectual Property Management of Directorate General for Research and Development Reinforcement Ministry of Research, Technology and Higher Education through the Overseas Seminar Aid Program, so that we can participate in CSSPO International Conference 2018 in Sarawak, 09 - 11 July 2018. This conference offers a great opportunity for academics and researchers to exchange ideas and also to build a network.

\section{References}

1. M. Singarimbun and S. Effendi, Survey Research Methods, (LP3ES, LP3ES, 2005)

2. Hayami and Ruttan, Agricultural Development An International Prespective, (The John Hopkins Press. Baltimore, London, 1989)

3. M. Hubeis, Toward a Small Professional Industry in the Era of Globalization through Empowerment of Industrial Management. Scientific Oration Professor of Permanent Management Science Industry. Faculty of Agricultural Technology. IPB. Bogor. (1997)

4. F. Hernanto, Agricultural Science, (Self-Help Publishers, Jakarta, 1996)

5. S. Hadi and N.F. Fauzi, Development Opportunity of Sea-Based Agroindustry in Payangan Village Sumberjo Subdistrict of Ambulu Jember Regency, Journal of Marine Fisheries 7, (2) (2016).

6. D. Soejono, Pattern of Agroindustry-Based Marine Fisheries Development in Puger, District of Jember, In J-SEP 2, (1) (2008) 